\title{
ODNOSI I VEZE U PRIGRANIČNIM PODRUČJIMA NA PRIMJERU HRVATSKO- SLOVENSKE GRANICE
}

\author{
Zoran Stiperski, ${ }^{*}$ Vera Kochi Pavlakovich**
}

\begin{abstract}
Izvleček
$\checkmark$ prispevku se poskuša dati odgovor na vprašanje o novem položaju lokalnih skupnosti ob slovensko - hrvaški meji po nastanku meddržavne meje 199| leta. Analiziran je le del obmejnega območja ob reki Sotli med mejnima prehodoma Maceli (Zagreb - Maribor) in Bregana (Zagreb - Ljubljana). Predstavljeni zaključki temeliijo na anketi predstavnikov lokalne politične oblasti in industriiskih obratov. Izstopajo tri značilnosti življenja lokalne skupnosti ob navedni meji: mirno obmejno sožitje, slabo gospodarsko in družbeno sodelovanje in počasno ločevanje.
\end{abstract}

Ključne besede: obmejno območje, hrvaško - slovenska meja, Sotla,prekomejno sodelovanje, lokalna skupnost, regionalna politika.

\section{RELATIONS AND CONNECTIONS IN BORDERLANDS ON THE EXAMPLE OF THE CROATIAN-SLOVENE BORDER}

\begin{abstract}
This work deals with the possibility of answering the question: which is the new reality of the local community in the Croatian borderland towards Slovenia after the border between the states of the former Yugoslavia became the interstate border in 1991? The whole borderland has not been analyzed, but only its part along the river Sutla between two border crossings: Maceli (Zagreb-Maribor) and Bregana (Zagreb-Ljubljana). The conclusions were brought out on the basis of the poll taken among the representatives of the local political authority and industrial firms. We come upon three basic life characteristics of this borderland local
\end{abstract}

* Dr., doc., Geografski odsjek, PMF, Sveučilište u Zagrebu, Maruličev trg 19, Zagreb, Hrvatska.

** Dr., red. prof., Department of Community and Economic Development, University of Arizona, USA. 
community: a peaceful coexistence, a weak economic and social cooperation, and a slight separation after the state border establishment.

Key Words: Borderlands, border, Croatian-Slovene border, Sutla, transborder cooperation, local community, regional policy.

\section{Uvod}

Kada se u hrvatskim krugovima govori o granicama uobičajeno se govori o političko-povijesnoj utemeljenosti granica. Većinu priča o granicama pokrenute su od strane političara, politologa i povjesničara. To je posljedica društvenog stanja na našim prostorima gdje su granice bile često predmet natezanja i sukoba. Radi toga granice bile su osobito zanimljive političkim geografima i povjesničarima. Ovdje će nas više zanimati kako živi lokalna zajednica uz granicu, u pograničnom području. Zanimat će nas pitanja o stupnju prekogranične suradnje, o institucionaliziranosti prekogranične suradnje, o procesima razdvajanja, o državnoj brizi za rubna, pogranična područja, o subjektivnoi pripadnosti lokalne sredine, i slično.

Prikaz granice na način koji mi pokušavamo sagledati u ovom radu već je dotaknuto u ranijim razmatranjima. Tako je Morehouse dala teoretske diskusije granica i graničnih područij. Clement (1997) ukazuje na učinak globalnih gospodarskih snaga na pogranična područja. $\bigcirc$ nedavnim političkim promjenama u Europi i njezinim posljedicama za Središnju, Istočnu i Jugoistočnu Europu pisali su Welsh (1997) i Klemenčić (1997). Posljedice koje su ostavili ti megatrendovi na lokalnoj i mikroregionalnoj razini razmatrane su s različitih naglasaka i iz različitih kutova, unutar posebnih lokalnih sklopova: američko-meksička granica (Wong, Llera), austrijsko-mađarska granica (WastlWalter, Varady), austriisko-slovenska granica (Janschitz, Kofler, 1997) i slovensko-hrvatska granica (Barbič, Ravbar).

Nedavna istraživanja slovenskih kolega, ponajviše Barbič (1996., 1997.) i Ravbar (1996., 1997.) zacrtali su osnovne učinke nove međunarodne granice iz pogleda općina na slovenskoj strani. Anketa provedena kod više od 300 kućanstava u dolini Posavske regije (Barbič 1996., 1997.) služi kao 
polazna točka za naš rad. U ovom radu nisu duplicirana izvješća kućanstava na hrvatskoj strani radi svrhe traženja statističke sličnosti ili različitosti između dvaju stanovništava, već ta izvješća koristiti prije kao dodatne informacije za širenje razumijevanja prostorno različitih procesa regionalnih transformacija.

\section{Studijsko područje}

Studijsko područje proteže se uz rijeku Sutlu, prirodnu granicu između Hrvatske i Slovenije. Obuhvaća prostor između dva granična prijalaza - Macelia i Bregane. Istodobno to studijsko područje predstavlja zapadni i sjeverozapadni rub zagrebačke regije. Deset općina graniči s međunarodnom granicom prema Sloveniji a pet općina fizički ne dodiruju graničnu liniju ali se nalaze $u$ neposrednoi blizini: urmanec, Hum na Sutli, Zagorska Sela, Kumrovec, Klanjec, Kraljevec na Sutli, Dubravica, Marija Gorica, Brdovec i Samobor. Pet općina u neposrednoj blizini su: Krapina, Pregrada, Desinić, Tuheli i Sveta Nedjelja. Usporedno područje u Sloveniji je posavska regija oko Brežica.

To je razmjerno malo područje, ali prostorno vrlo različito. Središnji dio je rijetko naseljeno ruralno područje s prevladavajuće planinsko-brdskom topografijom duž doline rijeke Sutle. Općine s obje strane su nerazvijena područja po standardima svake države. I prije utemeljenja međunarodne granice, to je područje imalo karakter periferije. Poljoprivreda malih, fragmentiranih polja $u$ kombinaciji s nešto industrije i usluga osnovni su izvor zarade za većinu stanovništva. Krajobraz na slovenskoj strani zapadno od rijeke Sutle i na hrvatskoj strani istočno od rijeke Sutle, sliči jedan na drugoga, ne samo u obliku fizičkih značajki, već također u obliku korištenja zemlje i načina života većine stanovništva.

Na sjevernom dijelu našega studijskog područja nalazi se nekoliko lokalnih središta - Hum na Sutli na hrvatskoj strani i Rogatec s obližnjom Rogaškom Slatinom na slovenskoj strani. Ta se središta razvijaju na temeljima lokalnih izvora (industrija stakla u Rogatecu i Humu na Sutli te lječilište u Rogaškoj Slatini) u kombinaciji s raspoloživom radnom snagom (jeftina radna snaga u susjednom ruralnom području, osobito na hrvatskoj strani, Hrvatsko zagorie). Neke lokalne specijalizacije razvile su se zajedno s profesionalnim znanjima (profesionalno oblikovanje stakla, lječilišne usluge). To se koristi za jedinstveno gospodarsko područje sa svojom lokalnom radnom snagom i prirodnim bogatstvima. Taj dio je svojevrsni hrvatsko-slovenski džep, barem za hrvatsku stranu. Naime, Hum 
na Sutli je prirodno-geografski više usmjeren na Rogatec i Rogašku Slatinu nego na Krapinu. Ta izvjesna prometna slabija povezanost s ostalim dijelovima Hrvatskog zagorja, koja je posljedica pružanja planina južno, uzrok je snažnijoi povezanosti $\mathrm{i}$ isprepletenosti hrvatske i slovenske strane. Ta se isprepletenost može vidjeti kroz znatno veću učestalost ženidbenih prekograničnih migracija nego u središnjem i južnom dijelu.

Najveće središte sjevernog dijela je Krapina. Premda nije na samoj granici, Krapina je podložna brojnim posljedicama od novih graničnih međuodnosa. Tamo se otvara carinarnica, špedicija, slobodna carinska zona i sl. Krapina je i administrativno središte Zagorsko-krapinske županije koja se podosta oslanja na granicu. U terminu fizičke lokacije, Krapina je bliža Sloveniji nego Zagrebu. Međutim, Krapina je povijesno usmierena na Zagreb. Poput drugih dijelova Hrvatskog zagoria, Krapina je bila izvor useljenika za Zagreb i druga industrijska središła uključujući Niemačku i ostale zapadnoeuropske države, s tendencijom pada zbog demografske starosti i boljih uvjeta života $u$ "starom kraju". Iseljeni radnici odnosno bivši stanovnici započinju sedamdesetih godina snažan val vraćanja kroz ulaganje u izgradnju kuća, uključujući vikendice i rekreacijske objekte. Krapina povezuje Zagreb i središnju Hrvatsku s Austrijom preko Ptuja i Maribora u Sloveniji, što predstavlja glavnu hrvatsku vezu sa Središnjom Europom u razdobliu poslije 1991. godine.

Hrvatski stanovnici koji su do 1991. g. radili na slovenskoj strani, većinom su izgubili posao, dok drugi, koji su uzeli slovensko državljanstvo, su ostali. Slovenci nisu radili u većem broju u zagrebačkoj regiii, premda zaposlenost u područiu Brežica i Čateža zavisi, jednim dijelom, od položaja u blizini velikog Zagreba. Naime, dio zagrebačkog dohotka troši se preko granice u Sloveniii ponajprije za rekreaciju (Čateške toplice, hoteli, restorani) i kupovinu. Te aktivnosti su smanjene $u$ poslijegraničnom razdoblju, premda oni su zamjenjeni s novim funkcijama, posebno novim graničnim sustavom trgovina.

Južni dio studijskog područja je razmjerno razvijeno područje. To je područje općina Brdovca, Samobora i Svete Nedjelje. Na neki način to je prošireni Zagreb. Tu se nalaze poneke ponajače hrvatske tvornice poput Plive (dio za temeljne kemijske sastojke) u Savskom Marofu, općina Brdovec. Samobor je poznat kao solidno razvijena sredina poznata po obrtu, industriii i izletništvu. Na području Svete Nedjelie, kao novooblikovane općine, niknulo je nekoliko poslovnih zona usluga, trgovine i industrije. 
U studijskom području najveći gradovi su Samobor s 15000 stanovnika (1991.) i Krapina s 5 000. Uz samu granicu naselja su još manja, najveće uz samu granicu na hrvatskoj strani je Hum na Sutli s 2000 stanovnika (1991.). Tamo nema nijedan okograničan grad ili grad-blizanac kao što su Gorica Nova Gorica duž talijansko-slovenske granice. Zapravo, jedini primjer gradablizanca na ovoj granici su Hum na Sutli-Rogatec.

\section{Podaci i metodologija}

Osnovni izvor podataka o perspektivi nove hrvatsko-slovenske granice bio je osobni intervju s predstavnicima petnaest graničnih općina (izabrane lokalne vlade) i predstavnicima industriijskih poduzeća (sedam u Samoboru i sedam u Krapini), provedene kroz kolovoz i rujan 1997. godine. lako izabrani službeno, predstavnici lokalnih vlada (načelnik ili gradonačelnik, čelnici općina ili gradova) su lokalni stanovnici, koji dobro poznaju stanje u svojim općinama. Oni su pitani da izraze zajednička ili većinska vjerovanja i poglede, premda je za očekivati da će svoj sud usmjeriti prema onom s kojim se i sami slažu. Predstarnici industrijskih poduzeća govorili su u svoje vlastito ime, ako je bilo pitanje o stavovima i sl., ili u ime svog poduzeća, ako je bilo pitanje o poslovnoj suradnii i slično.

Većina pitanja su ista kao u anketi na slovenskoj strani (Barbič 1997), s nekoliko manjih izuzetaka gdje se promijenilo zbog zahtjeva za osobito viđenje situacije u Hrvatskoj. Pitanja za hrvatski dio pograničnog područja bila su u svom izrazu prilagođena tako da se iznosi općeniti stav lokalne zajednice, a ne kao u slovenskoj anketi da se izrazi vlastiti stav. Odgovori od dviju studija - hrvatske i slovenske - nisu izravno usporedljive, zato što su postojale razlike u promatranom stanovništvu, ali anketa nudi koristan pogled u opće shvaćanje promjena prouzročene utemeljenjem međunarodne granice.

\section{Zaključno, kakav je život oko te granice?}

Na temelju 40-tak odgovora te uspoređujući odgovore sa slovenske strane, nameću se tri osnovna zaključka: 1) u pograničnom području između Bregane i Macelja živi se miran granični suživot, 2) slaba je društvena suradnja, a gospodarska gotovo da ne postoji, i 3) prisutno je lagano razdvajanje nakon utemelienja državne granice. U slijedeća tri poglavlja razmotrit ćemo te zaključke. 


\section{Mirni granični suživot}

Učestalost prelazaka granice. Uobičajeni prelasci stanovništva preko granice upućuju na miran granični suživot. Oko polovica ispitanika vjeruje da su prekogranični posjeti hrvatskih stanovnika smanjeni u odnosu na razdoblje prije osamostaljenja; premda trećina vieruje da učestalost prelazaka je ostao isti, dok neki vieruju da su ti prelasci pojačani. Ovo je u suprotnosti s opažajem slovenskih stanovnika, koji osjećaju da Hrvati prelaze granicu u većem broju nego prije (Barbič 1997). To može biti dijelom posljedica činjenice da je slovenski projekt fokusiran na područje Brežice, glavno trgovačko odredište, dok hrvatsko istraživanje uključuje izoliranija područja na sjeveru. Glavni spominjani razlozi za prelaske hrvatskih stanovnika su kupovina u slovenskim trgovinama i rad na polju s druge strane rijeke Sutle.

Opći je opažaj da slovenski stanovnici prelaze granicu rjeđe nego hrvatski i da su prelasci smanjeni u odnosu na razdoblje prije osamostaljenja. $U$ prošlosti, kada su cijene u lokalnim hrvatskim trgovinama bile niže nego $U$ Sloveniii, slovenski stanovnici dolazili su češće na hrvatsku stranu. Sada, od kada su cijene roba više u Hrvatskoj, slovenski stanovnici nisu motivirani za prekograničnu kupovinu, osim za neke ograničene usluge, rad na poljima na hrvatskoj strani, i posjeta samoborskom sajmu. $U$ tri od petnaest ispitanih općina, osjeća se da slovenski stanovnici uopće ne dolaze, dok u više od polovice, prelasci su smanjeni. Zanimljivo je, da na slovenskoj strani, preko 70 posto ispitanika ukazuje na istu ili višu učestalost graničnih prelazaka u usporedbi s razdobljem prije osamostaljenja (Barbič 1997.).

Sukobi duž granice. U većini ispitanih općina smatra se da sukoba nema. Slovenski stanovnici osjećaju više incidenata duž granice, premda je razmjerno mali postotak onih upletenih ili onih koji znaju za incidente. Taj dio granice možemo opisati kao miran (Barbič 1997.).

Odnosi između Hrvatske i Slovenije. Veze između Hrvatske i Slovenije, smatrane su kao "dobre" (prosječna ocjena je 3,3 na ljestvici od 1 do 5), premda veze između stanovništva na lokalnoj razini su smatrane boljim (prosječna ocjena 4,2). Važno je naglasiti da u niti jednoj hrvatskoj pograničnoj općini nije kazano da su odnosi sa Slovenijom loši (ocjena 2) ili izrazito loši (ocjena 1) što upućuje da u nijednoj lokalnoj sredini stanje nije zabrinjavajuće, odnosno da postoji krizno područje, područje sukobliavanja, netrpeliivosti i svađe. 
Međudržavni odnosi ne opterećuju lokalne prekogranične odnose. Opći je opažaj da brojni međudržavni problemi koji su nastali kao posljedica osamostaljivanja i sazrijevanja novih država, nisu bitnije opteretile lokalne prekogranične odnose. S hrvatske strane najčešće se spominju carinske odredbe, neriješen status pologa hrvatskih stanovnika u Ljubljanskoj banci, statusu dvonacionalne NE Krško i neriješeni granični problemi duž hrvatskoslovenske granice od kojih su najpoznatiji Piranski zaljev i Sveta Gera. Tu možemo zaključiti da osobna iskustva i obostrana međuzavisnosti čini temelj lokalnim prekograničnim vezama, dok su veze između država vođene političkim usmjerenjem i potrebama.

Novi odnosi nakon osamostaljenja. Kao što je bilo za očekivati, nitko ne vieruje da su utemeljenjem nove međunarodne granice pobolišani prekogranični odnosi. Većina vieruje da su odnosi između lokalnog stanovništva ostali isti u odnosu na razdoblje prije osamostaljenja.

\section{Slaba gospodarska i društvena suradnja}

Službena prekogranična suradnja. Službena prekogranična suradnja je rijetka, prema izvješćima sudionika na hrvatskoj strani. Od službenih aktivnosti, u primjetnijem obliku, spomenuta je jedino suradnja među vatrogascima s obje strane granice. Službena suradnja u pomalo deklarativnom obliku vidljiva je u vrijeme obiliežavanja Dana općine ili grada, kada se znadu pozvati i prekogranični predstavnici općina gdje se svi zalažu za jaču i tješniju prekograničnu suradnju, ali nakon proslave, ideja o prekograničnoj suradnii jenjava. Prema novijim informacijama iz Krapine opaža se tendencija smanjivanja želja za prekograničnom suradnjom na razini lokalnih političara. Drugi oblici prekogranične suradnje uključuju sudjelovanje $u$ kulturnim $i$ športskim događajima, uključujuči lov i ribolov. Možemo zaključiti da slovenski ispitanici misle kako je prekogranična suradnja intenzivnija nego što to misle hrvatski. Skoro polovica svih slovenskih ispitanika vjeruje kako granične općine surađuju u športskim aktivnostima, kulturnim i društvenim događajima, premda je razmjerno mali broj osoba u to uključen. Slovenska strana misli kako je ta vrsta prekogranične suradnje službeno poticana.

U više od trećini svih općina na hrvatskoj strani postoje zajednički problemi koji zahtjevaju jednu vrstu prekogranične suradnje. Najkonkretniii projekt bilo je rješavanje zagađenje rijeke Sutle u Humu na Sutli. Tamo je bilo dogovoreno, 
prema stanju iz 1997. g., da će slovenska strana uložiti tri četvrtine kapitala, a hrvatska jednu četvrtinu u ekološki projekt pročišćavanja voda rijeke Sutle. Odnos je određen udjelom u zagađivanju vode. Taj je projekt bio, s hrvatske strane, priželjkivan i pokazivan kao dobar primjer prekogranične suradnje u ovom hrvatsko-slovenskom džepu. Projekt nažalost nije ostvaren. Na kraju možemo spomenuti turistički vlak "Atomček" koji dolazi s turistima iz Atomskih toplica u Sloveniji jednom tiedno u Kumrovec.

Polaženje škola. Prema neslužbenim informacijama s hrvatske strane nijedno slovensko dijete ne polazi školu u Hrvatskoj, dok razmjerno mali broj djece iz hrvatskih sela polazi slovenske škole, većinom iz općina Džurmanec i Zagorska Sela, iz zabačenih hrvatskih sela, kojima su slovenske škole bliže nego hrvatske. Naime, ima nekoliko hrvatskih sela koja nemaju izravnu cestovnu vezu s ostalim dijelom Hrvatske, već se ona ostvaruje preko Slovenije. Tendencija ukazuje na sve slabije polaženje hrvatske djece u slovenske škole.

Trgovina između Hrvatske i Slovenije. Skoro svi vladini predstavnici zabiliežili su da je hrvatski izvoz u Sloveniju pao poslije utemeljenja međudržavne granice. Hrvatska je 1998. g. izvezla u Sloveniju 9,5\% vrijednosti svog ukupnog izvoza. Slovenija je četvrta zemlia za Hrvatsku po vrijednosti izvoza. S druge strane, Hrvatska je 1998. g. uvezla iz Slovenije 8,6 \% vrijednosti svog ukupnog uvoza. Ovdje je važno naglasiti da je Hrvatska 1998. g. imala u trgovini sa Slovenijom 289 milijuna američkih dolara manjka. To je peti po veličini trgovački manjak u hrvatskoj vanjskotrgovačkoj bilanci. Kada bi usporedili ove podatke iz 1998. g. s podacima iz 1992. mogli bi zaključiti da se neprekinuto smanjuje udjel Slovenije u hrvatskom izvozu i uvozu.

Anketirani predstavnici hrvatskih poduzeća su mišljenja, da je slovensko tržište zatvoreno za proizvode iz Hrvatske. Više od polovice ispitanih poduzeća kazali su, da je izvoz u Sloveniju pao u usporedbi s razdobljem od prije 1991. g., dok samo dvije tvrtke iz Samobora iskazale su povećanje svojih izvoznih aktivnosti. Hrvatski poslovni ljudi vide to stanje uglavnom kao posljedicu snažne slovenske kampanje kupovine proizvoda proizvedenih u Sloveniij.

Gospodarska prekogranična suradnja. Od 14 hrvatskih tvrtki iz Krapine i Samobora nitko nije naveo suradnju s prekograničnim slovenskim tvrtkama. Prema tom podatku možemo zaključiti da gospodarska prekogranična suradnja ne postoji. Nešto suradnje je zabilježeno između samoborskih i slovenskih trrtki, ali sve te slovenske tvrtke su iz Ljubliane ili Kranja, a ne iz obližnjeg slovensko-hrvatskog pograničnog područja. 
Nezakonita ekonomija. Nezakonite uvozno-izvozne aktivnosti postoje na obje strane granice. To je obostrano mišljenje, i hrvatske i slovenske strane. Slovenski ispitanici u području Brežica osjećaju više nezakonitih aktivnosti na svojem dijelu granice; oko polovica ispitanika vjeruje da pojedinci na obje strane granice su upleteni u nezakonitu trgovinu. To mišljenje većinom je utemeljeno na nekoj vidljivoj ubrzanoj gospodarskoj dobrobiti, većinom na skupim automobilima ili životnom stilu nedostupan većini stanovništva. Slovenci misle da nezakonita trgovina uključuje krijumčarenje žive stoke, kućanskih aparata, benzina, drva, oružja i useljenika bez dokumenata. $\mathrm{Na}$ hrvatskoj strani su spominjana neka sela koja se tradicionalno bave krijumčarenjem. U tim nekim selima, vieruje se, da je čak oko $30 \%$ stanovništva upleteno u prekogranično krijumčarenje što postaje vodeća gospodarska djelatnost. Krijumčarenje značajno povisuje dohodak lokalnom stanovništvu. Novi status stare granice, umjesto međurepubličke postaje međudržavnom, postaje povoljan za pojačanje krijumčarskih aktivnosti. Hrvatsko-slovenska granica na ovom dijelu prolazi rijekom Sutlom koja je mala i uska rijeka, gotovo potok. Rijeka Sutla, dakle, ne predstavlia veliku prirodnu barijeru između dviju država. Brojni mali mostovi na Sutli danas su zatvoreni i na njima nije organizirana granična i carinska služba što potiče propusnost granice, poželjno za krijumčare.

\section{Lagano razdvajanje nakon utemeljenja državne granice}

Promjena statusa iz međurepubličke u međudržavnu granicu izazvao je dva glavna šoka za lokalne zajednice. Prvi šok su doživjeli poljoprivrednici s obje strane granice, a drugi zaposleni Hrvati u Sloveniii.

Velik pad prodaje poljoprivrednih prekograničnih proizvoda. Utemeljenje međudržavne granice odrazilo se osobito nepovoljno za gospodarski status poljoprivrednika s obje strane granice. Hrvatski poljoprivrednici su prije prodavali znatan dio svojih proizvoda u Sloveniju. Taj manjak prodaje nisu uspjeli zadovoljavajuće nadoknaditi na hrvatskom tržištu. To je posljedica prekinute suradnje između hrvatskih poljoprivrednika i slovenskih poljoprivrednih zadruga, koje su znale otkuplijvati hrvatske poljoprivredne proizvode. Zanimljivo je da se većina hrvatskih ispitanika slaže da najveća razlika u hrvatskom i slovenskom pograničnom društvu vide upravo u stupnju organiziranosti i uspješnosti poljoprivrede: hrvatska strana misli da je 
poljoprivreda u Sloveniij znatno bolje organizirana i uspiešnija. Upravo sustav slovenskih poljoprivrednih zadruga je podosta zaslužan za takvu bolju organiziranost i uspješnost slovenske poljoprivrede u odnosu na hrvatsku. Sada je jasnije kakav je šok bio za hrvatske poljoprivrednike kada je prekinuta nihova veza sa slovenskim poljoprivrednim zadrugama.

Većina slovenskih ispitanika izvješćuje da je izvoz poljoprivrednih dobara u Hrvatsku drastično pao, prouzročivši stvarnu katastrofu za poljoprivrednike u području Brežica. Drastično je smanjena prodaja poljoprivrednih proizvoda brežičkih poljoprivrednika na velikom tržištu milijonske zagrebačke aglomeracije, koju slovenski poljoprivrednici iz Brežica ne mogu lako nadomjestiti.

Grupiranje poljoprivrednih imanja. Međudržavna granica je otežala prekograničnu obradu zemlje. Učestali prelasci graničnih prijelaza počinju zamarati poljoprivrednike. Brojni manji mostovi preko rijeke Sutle su zatvoreni, tako da poljoprivrednici moraju prijeći rijeku Sutlu na službenim graničnim prijelazima koji često znatno udaljuju poljoprivredno imanje. Sve to potiče tendenciju zamjene ili prodaje poljoprivrednih imanja s druge strane granice $s$ težnjom grupiranja na istoj strani granice gdje se stanuje.

Tržište radne snage. Opće je mišlienje da razmjerno mali broj hrvatskih i slovenskih stanovnika dnevno putuje preko granice. U razdoblju prije utemeljenja međudržavne granice učestalost prelaska granice radi zaposlenja bila je znatno veća: mnogo više Hrvata dnevno je putovalo na posao u Sloveniju. Hrvatima koji su radili u Sloveniji nakon osamostaljivanja dviju država ponuđeno je slovensko državljanstvo. Većina niih koji nisu prihvatili državljanstvo izgubila je svoj posao i vratila se u Hrvatsku. Bio je to poprilično jak gospodarski i društveni udarac za brojna sela u hrvatskom pograničnom području. Nije bilo više zarade koju su donosili, već se značajno povećala nezaposlenost i osjećai gospodarske bezperspektivnosti. Brz i jak pad zaposlenosti za Hrvate u Sloveniji ponajviše se osjećao u sjevernom i srednjem dijelu promatranoga hrvatskog pograničnog područja. Južni dijelovi, na području Brdovca, Samobora i Svete Nedjelje, nisu bili zahvaćeni tom pojavom, jer su obližnji Zagreb i lokalno gospodarstvo nudili dobre mogućnosti zaposlenja i nije bilo nužno tražiti posao s druge strane granice.

Hrvati koji su prihvatili slovensko državljanstvo, ostali su u Sloveniij. Samo manji broj Hrvata koji je odbio slovensko državljanstvo zadržao je posao i to su bili uglavnom specijalno izučeni ljudi te nisko plaćeni $i$ društveno 
vrednovani poslovi. Tako se spominje mala kolonija hrvatskih staklarskih majstora koji su, usprkos neprihvaćanju slovenskog državljanstva, u većini zadržali posao u staklarskoj industriji i obrtu rogaškog kraja, zbog nemogućnosti zadovoljavajuće zamjene.

Gubljenje zaposlenja Hrvata u Sloveniji nije samo posljedica političkih promjena, već i opći pad zaposlenosti kao posljedica prilagođavanja tržišnom gospodarstvu. Mnoge slovenske tvrtke morale su značajno smanjiti broj zaposleni.

Za razliku od Slovenije, Hrvatska nije bila naročito zanimljiva Slovencima za zaposlenje. U Hrvatskoi praktički nije bilo zahtjeva od slovenskih državljana za posao u hrvatskim tvrtkama. To je razumljivo iz više razloga, ovdje možemo kazati najmanje dva, što je Slovenija imala tradicionalno više plaće od Hrvatske i što je Slovenija dugi niz godina poticala ravnomierniji razvoj cijelog svog prostora.

\section{Na kraju, otvaraju se neka pitanja...}

Na kraju, otvaraju se neka pitanja o životu u pograničnom području nakon promjene statusa granice iz međurepubličke u međudržavnu. Ta brojna pitanja oko utjecaja i posljedica utemeljanja međudržavne granice za lokalna pogranična društva možemo sažeti u četiri pitanja. To su pitanja o procesima ujedinjenja-razjedinjenja, o prekograničnoj suradnji, o državnom poticanju razvoja lokalnih zajednica i o određenju-pripadnosti lokalne zajednice.

\section{Pitanje o procesima ujedinjenja-razjedinjenja}

Hrvatska i Slovenija bile su samostalne republike unutar iste države, što upućuje da su Hrvatska i Slovenija do jedne miere bile dvije razdvojene cijele. Prema tome, pitanje je koliko su Hrvatska i Slovenija bila stvarno jedna cjelina u vrijeme bivše Jugoslavije? Nepostajanje granice između Hrvatske i Slovenije i isti novčarski sustav su neke od neospornih činjenice, a ima ih više, da su Hrvatska i Slovenija bile jedna cjelina. Sada ćemo iznijeti jednu činjenicu koja će upućivati da su Hrvatska i Slovenija bile zapravo dvije različite cjeline, odnosno da je tadašnja međurepublička granica bila dosta jaka barijera. Zanimliivo je da na području Brežica nije 1988. g. bilo niti jednog pogona 
zagrebačke industrije. Te 1988. g. zagrebačka industrija imala je snagu podizanja svojih pogona izvan Zagreba do 80-tak kilometara udaljenosti, na području Središnje Hrvatske te, kao oaze, oko Rijeke kao najveće luke. U varaždinskom području koje je od Zagreba udaljenije za tri puta od Brežica, nalazilo se više desetaka pogona zagrebačke industrije, dok preko granice u Sloveniii, u Brežicama i sjevernije, nije bilo niti jednog pogona zagrebačke industrije. Tadašnja hrvatsko-slovenska međurepublička granica bila je velika barijera za izgradnju zagrebačke industrije i ona je više sličila međudržavnoj granici poput granici prema Mađarskoj nego nekoj unutardržavnoi međurepubličkoi granici. Možemo zakliučiti da se Hrvatska i Slovenija u vrijeme bivše Jugoslavije bile, po nekim elementima, dvije cjeline, a po nekim drugim elementima, jedna cjelina. To nas navodi na zaključak da dezintegrativni proces u hrvatsko-slovenskom pograničnom području nije toliko izrazit, već da je više riječ o laganom razdvajanju.

\section{Pitanje o prekograničnoj suradnji}

Prekogranična suradnja ovisi o interesima, koristima, upućenostima i nadopunjavanjima obje strane oko granice. Suvremene politike Europske unije i globalnog svijeta potiču, barem deklarativno, prekograničnu suradnju koja se u višoj etapi institucionalizira. Tvrde, opasne i teško prolazne granice te granice bez gospodarske ili kulturne suradnje nisu popularni oblici granica za današnji globalni svijet. Sada možemo postaviti pitanje. Zašto je prekogranična suradnja na hrvatsko-slovenskoj granici razmierno slabije jakosti, pogotovo ako usporedimo poznate svjetske primjere poput američkomeksičke granice?(Pavlakovich, 1997; Pavlakovich, Stiperski, 1997) Tu vidimo tri moguća odgovora. Prvo je pitanje veličine. Činjenica je da i Hrvatska i Slovenija nemaju veliku gospodarsku i demografsku masu. Granica je linija gdje se sučeljavaju, dodirivaju i preklapaju dva društva. Mala masa ukazuje na manji potencijal. Za očekivati je da se ne može na hrvatsko-slovenskoj granici očekivati veliko sučeljavanje kada su mase male. Drugo je pitanje gospodarske razvijenosti. Slovenija je nešto razvijenija od Hrvatske, ali ipak možemo kazati da nema znatnije gospodarske razlike u stupnju razvijenosti. Za postojanje tvornica koje će iskorištavati jeftinu radnu snagu, kao američke tvornice na meksičkom pograničnom prostoru, razlika u razvijenosti između Hrvatske i Slovenije nije dovoljna. Slovenija nije dovoljno razvijena, te nema 
snažnih tvrtki koje su značajno prisutne na svjetskom tržištu da bi mogle graditi pogone u siromašnijim društvima radi korištenja jeftine radne snage. $S$ druge strane, hrvatske prosječne plaće su razmjerno visoke, do slovenskih najviše u postsocijalističkoj Europi. Sve to onemogućuje nicanje slovenskih pogona na hrvatskom pograničnom području radi korištenja jeftine radne snage. Treća činjenica je u sferi subjektivne upućenosti. Postoji osjećaj da sve postsocijalističke zemlje teže dobrim vezama sa Zapadnom Europom (Europskom unijom) a ne međusobnim vezama. S tim u skladu, čini se da je Slovenija više subjektivno upućena prema Austriji, Italiii, pa i Mađarskoj, nego prema Hrvatskoj. To nam se čini isto jednim od mogućih faktora slabijoj gospodarskoi prekograničnoj suradnii na hrvatsko-slovenskoi granici.

\section{O državnom poticanju razvoja lokalnih zajednica}

Nove nezavisne države ne pridaju veliku važnost lokalnoj i mikroregionalnoj razini. Razlog je u nedovolinoj osnaženosti te nužnosti postignuća i riešavanja gorućih problema važnih za cijelu državu. Mlade države se vobičajeno nađu s tim problemima. Kada se, pod uvjetom da uspije, država osnaži i riješi sve svoje strateške potrebe tada se otvara mogućnost za razvoj lokalnih sredina. S gospodarskom razvijenošću javlja se, barem na deklarativnoj razini, osjećaj - potrebi razvoja lokalnih sredina. Tu moramo kazati da globalno doba preferira velike sredine, gradove, koji dobiju još veći značaj i privlačnost. lako se u globalnim odnosima ruše granice, informacije brzo dolaze u male sredine, ali ipak raste privlačna moć velikih gradov. Pitanje je, koliko država potiče razvoj lokalnih zajednica.

Dvije trećine ispitanika na hrvatskoj strani vjeruje da središnja vlada u Hrvatskoi pokazuje malo zanimanja za razvoj graničnih regija. Samo jedan ispitanik ima mišljenje da granično područje ima više pozornosti nego ostali dijelovi države.

\section{O određivanju/pripadnosti lokalne zajednice}

Posljednje pitanje govori o osjećaju pripadnosti koji postoji u lokalnoj zajednici. Tim se osjećajem vidi stav o pripadnosti odnosno gdje lokalna zajednica vidi svoje miesto. To smo pitanje naglasili jer smo u anketiranju 
hrvatske strane vidjeli jedan zanimljiv odgovor. Većina ispitanika s hrvatske strane ukazuje kako je glavni problem za njihove, inače pogranične, općine slaba prometna povezanost sa Zagrebom. Tako ispada da hrvatsko pogranično područje vidi svoju budućnost u suradnii sa Zagrebom, a ne sa Slovenijom odnosno slovenskim pograničnim područjem. Ili, problematika pograničnih područja nije nešto naročito zanimljivo za hrvatsku stranu. To je za nju više deklarativno, i ne previše strateški važno pitanje oko koje bi vezali svoju budućnost. Svoju budućnost, odnosno dobru mogućnost za gospodarski razvoj vežu za Zagreb. Na kraju možemo postaviti pitanje: Je li se hrvatsko pogranično područje uz granicu između Macelja i Bregane više osjeća pograničnim područjem ili zagrebačkom regijom? Na temeliu anketnih odgovora naslućuje se da se hrvatsko pogranično područje osjeća više rubom zagrebačke regije nego pograničnim područjem.

\section{Zaključak}

Na brojna pitanja koja se mogu svesti na jedno - Kako živi lokalna zajednica uz hrvatsko-slovensku granicu između Macelja i Bregane nakon osamostaljivanja dviju država 1991. g. - izranjaju tri osnovne grupe zaključaka:

1. Granica je mirna. Odnosi između Hrvatske i Slovenije ocijenjeni su dobrim, a oni na lokalnoj razini još boljim. Granica nije bitnije opterećena incidentima. Problemi koji opterećuju hrvatsko-slovenske odnose na državnoj razini - poput duga Ljubljanske banke hrvatskim štedišima, statusu dvonacionalne NE Krško, neriješni granični problemi u Piranskom zaljevu, Svetoj Geri - ne opterećuju bitnije odnose na lokalnoj razini.

2. Slaba gospodarska $i$ društvena prekogranična suradnja. Nijedna industrijska tvrtka iz Krapine i Samobora poslovno ne surađuje sa slovenskom tvrrkom iz obližnjega prekograničnog područja. Društvena prekogranična suradnja je slaba i na "preniskoj" razini. Surađuju samo lokalni vatrogasci, športaši, ribiči, lovci i umjetnici. Nije zabiliežen niti jedan zajednički projekt poput ekološkog, poslovnog ili turističkog.

3. Lagano razdvajanje nakon utemeljanja državne granice. Najveće razdvajanje desilo se u poljoprivrednom sektoru - došlo je do značajnog pada prekogranične prodaje poljoprivrednih proizvoda u oba smiera. Drugi šok doživjeli su Hrvati koji su radili u Sloveniii, jer je većina izgubila posao. 


\section{Literatura}

Barbič A.., 1997: Coping with new realities: The Slovenian-Croatian Border. Klagenfurt-Ljubljana, International Conference: Challenged Borderlands Transcending Political and Cultural Boundaries, 24 str. (rukopis)

Clement N., 1997: Economic Forces Shaping the Borderlands. KlagenfurtLjubliana, International Conference: Challenged Borderlands Transcending Political and Cultural Boundaries, 18 str. (rukopis)

Gonzalez P. W., 1997: Conflict and Accomodation in the Arizona-Sonora Region. Klagenfurt-Ljubliana, International Conference: Challenged Borderlands Transcending Political and Cultural Boundaries, 18 str. (rukopis)

Grundwald J., Flamm K., 1985: The Global Factory: Foreign Assembly in International Trade. Washington, D.C., Brookings Institution.

Hajdu Z., 1997: Dilemmas and Chances for Renewal of the Cross-border Cooperation along the Hungarian-Croatian State Border. KlagenfurtLjubliana, International Conference: Challenged Borderlands Transcending Political and Cultural Boundaries, 15 str. (rukopis)

Hendersen J., Castells M., 1987: Global Restructuring and Territorial Development. London \& Newburry Park, SAGE Publications.

Janschitz S., Kofler A., 1997: Chances to protect diversities and emphasize commonalities in a multicultural living space. Klagenfurt-Ljubljana, International Conference: Challenged Borderlands - Transcending Political and Cultural Boundaries, 15 str. (rukopis)

Klemenčić M., Schofield C., 1997: Contested Borders and Boundaries. Klagenfurt-Ljubljana, International Conference: Challenged Borderlands Transcending Political and Cultural Boundaries, 11 str. (rukopis)

Ohmae K., 1993: Rise of the Region State, Foreign Affairs (Spring), 78-87. str.

Pacheco F. J. L., 1997: The Growth Machine in El Paso-Ciudad Juarez Region. Klagenfurt-Liubliana, International Conference: Challenged Borderlands Transcending Political and Cultural Boundaries, 24 str. (rukopis)

Pavlakovich V., 1994: The United States-Mexico Borderland: "Where North Meets South" or "Marriage of Convenience". Zagreb, Geografski glasnik, Vol. 56., Hrvatsko geografsko društvo, 1-19. str.

Pavlakovich V., Stiperski Z., 1997: The Zagreb Region at the Double Doorsteps. Klagenfurt-Ljubliana, International Conference: Challenged Borderlands Transcending Political and Cultural Boundaries, 17 str. (rukopis) 
Ravbar M., 1997: The Slovenian-Croatian Border: Border Areas in Slovenia along the Slovenian Croatian Border in the Light of Transborder Cooperation. Klagenfurt-Ljubliana, International Conference: Challenged Borderlands Transcending Political and Cultural Boundaries, 15 str. (rukopis)

Welch R., 1997: From Iron Curtain to Fortress Europe. Klagenfurt-Liubliana, International Conference: Challenged Borderlands - Transcending Political and Cultural Boundaries, 15 str. (rukopis)

\section{RELATIONS AND CONNECTIONS IN BORDERLANDS ON THE EXAMPLE OF THE CROATIAN-SLOVENE BORDER}

\section{Summary}

How can we describe the life of the local community by the CroatianSlovene border between Maceli and Bregana after the two states became independent in 1991? There are three groups of conclusions:

1. A peaceful border. The relations between Croatia and Slovenia have been evaluated as good, and those on the local level even better. The border is not essentially burdened by incidents. The problems burdening the CroatianSlovene relations on the state level - such as the debt of the Bank of Liubliana to the Croatian thrifty persons, the status of the binational nuclear power plant Krško, the unsolved border problems in the Bay of Piran and Sveta Gera - do not burden essentially the relations on the local level.

2. A weak economic and social transborder cooperation. Not a single industrial firm from Krapina and Samobor make business with any Slovene firm from the neighbouring transborder area. The social transborder cooperation is weak and on a "too low" level. It can be noticed only among the local firemen, sportsmen, fishermen, hunters and artists. Not a single common ecological, business or tourist project has been registered.

3. A slight separation after the state border establishment. The greatest separation took place in the agricultural sector - there was a significant decrease of the transborder sale of agricultural products in both directions. The Croats working in Slovenia received a rude shock: the majority of them lost their job. 